in the history of Limnology \& Oceanography as well as ASLO's other publishing activities. He served as Editor-in-Chief for LEO from 1986 to 1992 . In about the middle of that term, in part to allow his escape, he oversaw transition from a sole editorship to a board of associate editors. Later, Pete served on the LEO Editorial Advisory Committee (1995 - 1997). Since 2005, Pete has served as the Associate Editor for Scholarly Reviews for LEO. Since 2006, he has chaired the ad hoc Committee on Open Access and has led a vigorous discussion of the pros and cons of the open-access movement, which inevitably will have enormous consequences for the society. As members of the open-access committee, we can attest to Pete's commitment to helping ASLO make well-informed decisions regarding open-access publishing. Remarkably, Pete also serves on two other working groups considering new publications: the ad hoc committee to evaluate the proposed Limnology and Oceanography: Environments and Fluids journal, and the ad hoc committee on web books.

Pete has also helped build ASLO's influence in the broader scientific community. Since 2003, Pete has participated in the Council of Scientific Society Presidents (CSSP), an umbrella organization for professional scientific societies. During the semi-annual meetings, presidents of societies from all disciplines of science discuss issues of common interest and concern, ranging from research funding to publications to new regulations for non profits. Pete served enthusiastically on the Council while he was President, and agreed to continue serving beyond his term. During that time, he was elected as Secretary, then Treasurer and for 2008 as Chair of the Council, an honor that attests to the respect our colleagues outside of limnology and oceanography have for Pete. Pete's participation in CSSP benefits ASLO in terms of learning from the experiences of other societies and networking with high-ranking policy officials. Additionally, Pete has been able to move several issues of import to ASLO, such as freshwater research, to the CSSP's priority list, thereby adding the weight of CSSP's sixty member societies (and their 1.4 million members) to ASLO's causes.

Eleven years ago, ASLO recognized Pete Jumars' scientific achievements with the Hutchinson award. This year, ASLO is pleased to recognize Pete's service to the society with the ASLO Distinguished Service Award.

\section{A. C. REDFIELD LIFETIME ACHIEVEMENT AWARD TO JOHN HOBBIE}

Cited by George Kling, University of Michigan, Ann Arbor, Michigan, USA

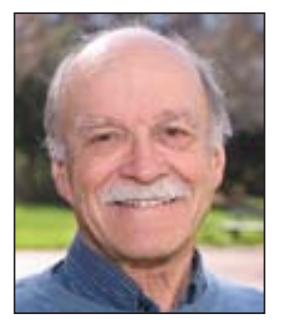

John Hobbie is a limnologist cut from the Hutchinsonian cloth, where individual scientists learned the physics, chemistry, and biology of a system and then synthesized it into a vibrant picture of the whole. This system approach has always governed John's thinking, and has been most prominent in his research on estuaries and arctic lakes.

Fortunately for us, Hobbie developed a keen curiosity for microbes within this ecosystem framework, which has not only driven his research for almost 50 years but has forced us to change the way we do our science. His first of two seminal breakthroughs in aquatic ecology was to use radioisotopes to study microbial activity in lakes and oceans. Along with Dick Wright, a fellow post-doc at Uppsala, he used these techniques to carve out from the classic field of microbiology the pioneer field of microbial ecology. Before that time we knew what microbes did in the laboratory, but only with these careful studies and experiments did we, for the first time, understand what microbes really do in nature. Although this helped spawn the field of microbial ecology, we still lacked the ability to combine measures of natural rates of activity with the information about populations so easily found on an agar plate. In his second seminal contribution to the field, Hobbie, along with Daley and Jasper, solved that problem as well by developing the "Use of Nuclepore filters for counting bacteria by fluorescence microscopy" (currently at 3,200+ citations). Ecologists now had the breakthrough to study both the population dynamics and the ecosystem function of the most diverse and abundant group of organisms on Earth. These approaches, coupled with others' ideas about the "microbial loop," stimulated our progress for the next 20 years. And beyond that, John has kept abreast of newer molecular techniques and insists that his colleagues and students use them, assuring his continuing presence and importance in ecology. In fact, he just published a paper with his son on the role of soil microbes in fueling plant nutrient uptake - some reviews judge it to be just the kind of novel paper that foreshadows the next great science advance.

Hobbie's contributions and service to our society and the scientific community are as stellar as his research. He served as ASLO president and president of the Association of Ecosystem Research Centers, and as a member of the U.S. Arctic Research Commission (appointed by the President), the Board of Directors of the Arctic Research Consortium of the U.S., and the Ocean Studies Board and Polar Research Board of the National Academy of Sciences. His indispensable leadership in scientific programs started with his role in the International Biological Programme (IBP) of the 1960s (led the aquatic Tundra Biome), and continued with the directorship of the Ecosystem Center of the Marine Biological Laboratory starting in 1984, the National Science Foundation's Long Term Ecological Research program developed in the 1980s (directs the Arctic LTER site), the inclusion of coastal research (he managed the NSF Land-Margin Ecosystems Research (LMER) program) into the LTER program in the 1990s, and still today with the development of the National Ecological Observatory Network (NEON) site in the Arctic. John has served on countless regional, national, and international committees, and through it all his tireless effort has been driven by a commitment to promote science at all levels, and in all forms.

As with many human endeavors, some of our most important accomplishments are poorly recorded on paper. Although John's exposure to students has been limited due to his non-academic position, to all who've met him he is a pillar of clear thinking and an inspiration for achieving excellence in science. John loves the competition of intellectual challenge, and if he listens and then agrees with your ideas you've really won a battle. My favorite example that reflects on Hobbie's rare combination of intellectual competitiveness and personal understatement, was at an ASLO 
meeting when sitting with me and another colleague on a bench outside during a break, Hobbie was approached by a well-known and ambitious younger scientist, who, trailed by a gaggle of students from his lab, confronted John by loudly announcing that his newest paper "will blow your Citation Classic out of the water!". Quite nonchalantly and with gentlemanly aplomb, Hobbie paused for a second then simply replied "which one?"

Despite the fact that John eschews publicity he has received great honors, including the Hutchinson Award from our society and the Odum Award from the Estuarine Research Federation. Last year John was named "Distinguished Scientist" at the Marine Biological Laboratory, a special recognition bestowed for outstanding research accomplishments and service to the scientific community - only one other person has achieved this status in the 120-year history of this Institution. John Hobbie is most deserving of this Redfield Award, and we are indeed fortunate to have him among our ranks.

\section{RUTH PATRICK AWARD TO NANCY RABALAIS}

Cited by Don Boesch, University of Maryland, Center for

Environmental Science, Cambridge, Maryland, USA

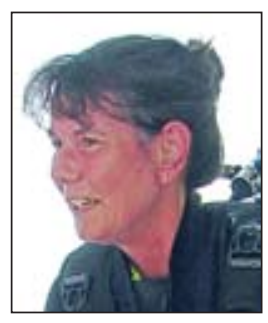

Professor Nancy Rabalais has embodied the spirit of Dr. Ruth Patrick who recently celebrated her 100th birthday last November. Nancy has devoted her energies in the tradition of Ruth Patrick, achieving outstanding accomplishments in the application of diverse scientific principles toward the identification, analysis, and solution of one of the most significant environmental problems in aquatic environments - the dramatic expansion of hypoxia in coastal waters during the latter part of the 20th century.

Nancy Rabalais came to the Louisiana Universities Marine Consortium as a post-doc, where she is now the Executive Director. After initially working on oil pollution issues, she assumed the leadership of nascent research efforts to describe and understand hypoxia in bottom waters of the vast Louisiana continental shelf, a phenomenon for which only scant information was previously available. The obstacles Nancy faced were enormous: logistics, funding, dynamic complexity, and, particularly, skepticism and denial. By the late 1980s she and her collaborators were able to demonstrate that hypoxia was extensive not patchy, seasonally continuous not ephemeral, and closely linked with the delivery of fresh water and anthropogenic nutrients from the Mississippi-Atchafalaya river system.

Through long-term and highly productive collaborations with a number of investigators, Nancy Rabalais has described the dynamics of Gulf of Mexico hypoxia, its history, its relationship to increased delivery of nutrients by the rivers, its effects on benthic biota and living resources, nutrient cycling, underlying changes in the Mississippi River basin, and requirements for the alleviation of hypoxia. This work has embraced physical oceanography, hydrology, geochemistry, paleontology, modeling, and ecology.

The work of Rabalais et al. has had a major effect on national policies and programs. Concern generated about the scale of Gulf hypoxia contributed directly to the enactment of the Harmful Algal Bloom and Hypoxia Research and Control Act of 1998. Their findings provided the foundation for the Integrated Assessment of Hypoxia in the Northern Gulf of Mexico in 2000 and the Action Plan for Reducing, Mitigating, and Controlling Hypoxia in 2001 - the draft update of which reaffirms the earlier goals and requirements for abatement. Nancy has courageously appeared in the Midwest heartland to explain why nutrient runoff from farms was the principal cause of hypoxia to disbelieving and often angry agriculturalists. And, she has extended her work and influence beyond the region of her principal research.

Prof. Nancy Rabalais is a tireless scientific citizen and leader, giving freely of her time, abilities, and insights. She served on National Research Council committees dealing with oil and the sea, USGS coastal programs, and water quality in the Mississippi River basin. She was appointed to the Ocean Studies Board of the National Research Council in 2000 and served as its chair from 2002 to 2005-the first woman chair and the first chair not from a major oceanographic institution. In the Ruth Patrick tradition she has broken glass ceilings based not only on gender, but also on geography, institutional status, and salinity. She served as a member of the U.S. Ocean Research and Resources Advisory Panel that has advised the Federal government on the President's Ocean Action Plan and, internationally, serves on the Scientific Steering Committee for the LandOcean Interactions in the Coastal Zone Programme (IGBP).

\section{JOHN MARTIN AWARD TO EPPLEY \& PETERSEN 1979}

Cited by Cindy Lee, Stony Brook University, Stony Brook, New

York, USA and George McManus, University of Connecticut, Groton, Connecticut, USA

Eppley, R. and B. Peterson. 1979. Particulate organic matter flux and planktonic new production in the deep ocean. Nature 282: 677-680.

In this paper, Eppley and Peterson emphasized that the vertical flux of material out of the photic zone must be balanced globally by "new" production based on imported sources of N (cross-pycnocline mixing, $\mathrm{N}$-fixation, etc.). Dugdale and Goering ( $\mathrm{LEO}$ $1967,12: 196)$ had made the original distinction between 'new'

\section{Particulate organic matter flux and planktonic new production in the deep ocean}

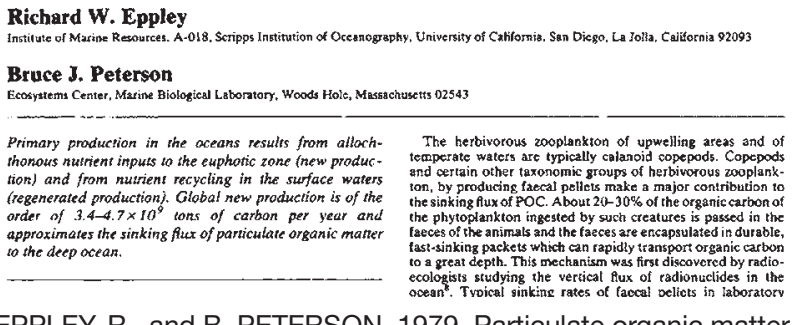

EPPLEY, R., and B. PETERSON. 1979. Particulate organic matter flux and planktonic new production in the deep ocean. Nature 282: $677-680$. 